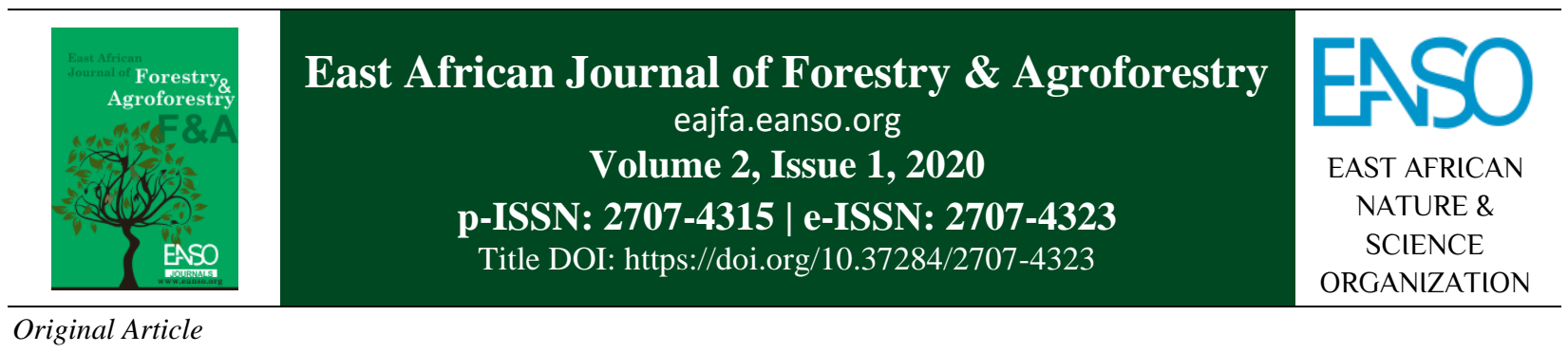

\title{
Effects of Land Use and Land Cover Change on Tse Gavar community Forest, Vandeikya Local Government Area, Benue State, Nigeria
}

\author{
Dr. Emmanuel Tertsea Ikyaagba ${ }^{*}$, Joseph Asen Jande $^{1} \&$ Mercy Kpadoo Abiem $^{1}$ \\ ${ }^{1}$ Department of Social and Environmental Forestry, University of Agriculture, Makurdi, Nigeria. \\ *Author for Correspondence email: ikyaagbater@ gmail.com.
}

Article DOI: https://doi.org/10.37284/eajfa.2.1.127

\author{
Article history: \\ Received: 11 Jan 2020 \\ Accepted: 30 Jan 2020 \\ Published: 28 Mar 2020 \\ Keywords: \\ Tse Gavar, \\ Land Use, \\ Land Cover, \\ Community Forest, \\ Forest Reserve, \\ Supervised \\ Classification.
}

\begin{abstract}
Forests are considered to be the very basis for human existence as they touch virtually every aspect of human endeavour. Despite the numerous benefits of forests, the world is experiencing unprecedented degradation of forest and its resources; this is mainly attributed to land use and land cover (LULC) change. Therefore, monitoring of these changes has become a necessity. Hence, the use of remotely sensed data in conjunction with GIS for LULC analysis of Tse Gavar community forest in Vandeikya Local Government Area would provide the needed data for sustainable forest management as well as promote community forest in the State. This study made use of mostly secondary data from pre-existing satellites imageries. The Landsat TM for 1986, Landsat ETM+ for 2001 and 2012 as well as OLI for 2018 images were gotten from the Earthexplorer, Global Land Cover Facility (GLCF) and GloVis platforms. Imageries were processed and then classified using a supervised approach. The result of the classification revealed four classes of farmland, other vegetation, forest area and bare land. The percentage of LULC in Tse Gavar community forest indicated that farmland increased from $5.78 \%$ in 1986 to $18.25 \%$ in 2018. Shrubland also increased from $3.06 \%$ in 1986 to $21.08 \%$ in 2018 . The forest area declined from $84.17 \%$ in 1986 to $59.38 \%$ in 2018 . The magnitude of LULC change within the 32 years period showed that $9.36 \mathrm{Ha}$ of the forest area was lost to other forms of land use, the bare land area lost within the period was 0.09 Ha to other land uses. Farmland area rose by $4.32 \mathrm{Ha}$ within the period, shrubland increased by $5078.88 \mathrm{~km}^{2}$. It was established that just like other protected areas, LULC changes are going on in the Tse Gavar community forest reserve. The study recommended the reforestation of the reserve.
\end{abstract}




\section{APA CITATION}

Ikyaagba, E., Jande, J., \& Abiem, M. (2020). Effects of Land Use and Land Cover Change on Tse Gavar community forest, Vandeikya Local Government Area, Benue State, Nigeria. East African Journal of Forestry and Agroforestry, 2(1), 34-46. https://doi.org/10.37284/eajfa.2.1.127

\section{CHICAGO CITATION}

Ikyaagba, Emmanuel, Joseph Jande, and Mercy Abiem. 2020. "Effects of Land Use and Land Cover Change on Tse Gavar community forest, Vandeikya Local Government Area, Benue State, Nigeria". East African Journal of Forestry and Agroforestry 2 (1), 34-46. https://doi.org/10.37284/eajfa.2.1.127.

\section{HARVARD CITATION}

Ikyaagba, E., Jande, J. and Abiem, M. (2020) "Effects of Land Use and Land Cover Change on Tse Gavar community forest, Vandeikya Local Government Area, Benue State, Nigeria", East African Journal of Forestry and Agroforestry, 2(1), pp. 34-46. doi: 10.37284/eajfa.2.1.127.

\section{IEEE CITATION}

E. Ikyaagba, J. Jande, and M. Abiem, "Effects of Land Use and Land Cover Change on Tse Gavar community forest, Vandeikya Local Government Area, Benue State, Nigeria”, EAJFA, vol. 2, no. 1, pp. 34-46, Apr. 2020.

\section{MLA CITATION}

Ikyaagba, Emmanuel, Joseph Jande, and Mercy Abiem. "Effects of Land Use and Land Cover Change on Tse Gavar community forest, Vandeikya Local Government Area, Benue State, Nigeria". East African Journal of Forestry and Agroforestry, Vol. 2, no. 1, Apr. 2020, pp. 34-46, doi:10.37284/eajfa.2.1.127.

\section{INTRODUCTION}

Throughout the existence of humanity on earth, forests and trees have been of immense benefit to mankind through the provision of food, income, shelter, fibre, energy, medicine, building materials, fodder, and inspiration (Powell et al., 2013; FAO, 2018; Gabay and Rekola, 2019). Forests and trees are essential to livelihoods, sustainable agriculture, climate change mitigation and adaptation, resilience, renewable energy as well as regulation of the water cycle (FAO, 2018). According to FAO (2018) over 2.5 billion people all over the world that are involved in subsistence agriculture benefit from the ecosystem services provided by the forest. Despite the numerous benefits of the forests, the world is experiencing unprecedented degradation of forests and its resources mainly due to LULC change.

Land-use change is considered as a major threat to biodiversity due to the fact that other threats to biodiversity are stimulated by changes in land use. Also, it is believed to be a major threat due to its devastating effects on habitat availability and consequently the loss of biodiversity (Adedeji et al., 2015; Sala et al., 2000). Laurance (2010) referred to the loss and degradation of natural habitats due to change in land use as a war of attrition. Forests have been affected especially hard denoted by the extreme decline of the global forests area. Over $130,000 \mathrm{~km}^{2}$ of tropical forests are lost yearly. This is roughly 50 football fields in a minute (Laurance, 2010). This disappearance is not only restricted to non-formally protected forest as both protected areas (PAs) and community forests are also experiencing LULC changes (Defries et al., 2007; Scholte, 2011; Faye et al., 2016)

LULC change referred to the human modification of land. Over the years, humans have been modifying land for livelihood activities, however, the current rates, extents and intensities of LULC change are far more than the change ever recorded in history (Defries et al., 2007). The modifications bring about changes in the ecosystems and environmental processes at levels. The changes that we are witnessing today generate a lot of environmental problems for human populations. Some of these include climate change, biodiversity loss as well as water, air and soil. Therefore, it is imperative for researchers and policymakers around the world to monitor and mediate the negative consequences of LULC change, at the same time sustaining the production of essential resources (Ellis and Pontius, 2010). 
Even though several types of research have been carried out in conventional systems to generate data on the LULC in other parts of Nigeria particularly in forest reserves (Mohammed et al., 2013; Ikusemoran and Olokor, 2014; Jande et al., 2018). Few studies have been done on LULC in forests managed by communities using Geographic Information System (GIS) and Remote Sensing approaches, particularly in Benue State. Therefore, the use of remotely sensed data in conjunction with GIS for LULC analysis of Tse Gavar community forest in Vandeikya Local Government Area would provide the needed data for sustainable forest management as well as promote community forest in the State.

\section{MATERIALS AND METHODS}

\section{Study Area}

Vandeikya Local Government Area is located between latitude $7^{\circ} 5^{\prime}$ and $7^{\circ} 15^{\prime} \mathrm{N}$, longitude $9^{\circ}$ and $9^{\circ} 6^{\prime}$ E. It has a landmass of 183,939 square kilometres (Agera et al., 2010) with a projected population of 316,600 (Iorkosu et al., 2019). Vandeikya local government shares boundaries with some local governments in Cross River State. These include; Obudu and Bekwara to the East. Within Benue State, it shared boundaries with Ushongo to the North and Konshisha LGA to the West. The local government is made up of twelve council wards.
Vandeikya Local Government Area has two seasons, the wet and dry seasons. The wet (raining) season starts in April and ends in October. The dry season normally starts in November and ends in March. The annual rainfall ranges from 1500 to $1750 \mathrm{~mm}$. Temperatures in the area are usually very high $\left(30-35{ }^{\circ} \mathrm{C}\right)$ particularly in March and April (Agera et al., 2010). The vegetation of the area is that of Guinea Savanna, vegetation is made of fireresistant trees species together with giant grasses. Some the tree species include; Iruingia gabonensis, Daniellia olliveri, Prosopis africana (Red mortar wood) Parkia biglobosa (locust bean plant), Khaya senegalensis (Dry zone Mahogany), Dialium guineense (velvet Tamarind), Syzygium guineense, Lophira lanceolata (Red ironwood), and Vitex doniana (Black plum). Most of the grasses are perennial, they include Hyparrhenia involucruta, Andropogon gayanus, Loudetia flavida, Pennisetum purpureum, Panicum unerimum, Pennisetum unisetum and Digitaria hirizontalis among others. The area is low land undulated. The major water bodies in the local government include; river Be, river Aya, river Sambe and river Uaghshu (Agera et al., 2010). Tiv is the major tribe in the area and the majority of the people are subsistence farmers. Crops produced by the people in the area include; yam, Groundnut, cassava, maize, melon, pepper and cocoyam. Apart from community forests, there are also forest plantations established by the government between 1945 and 1970 (Agera et al., 2010). Gmelina arborea and Tectona grandis were the exotics species used for the establishment of those plantations. 
Figure 1: Map of Benue State showing Study Area

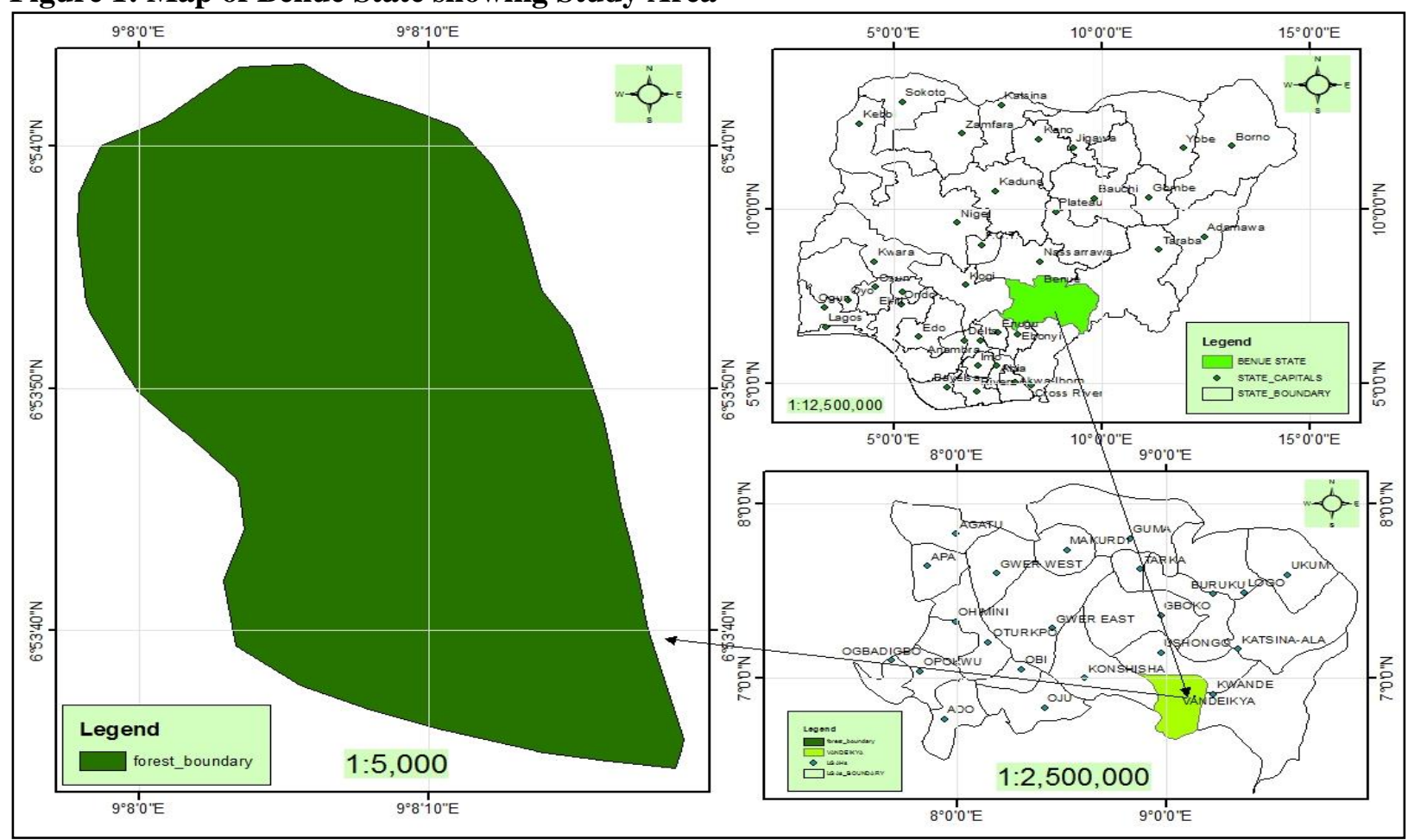

\section{Data Source and Collection}

This study made use of mostly secondary data from pre-existing satellites imageries. The Landsat TM for 1986, Landsat ETM+ for 2001 and 2012 and OLI for 2018 images were sourced from the Earthexplorer platform from United States Geological Surveys (USGS), Global Land Cover Facility (GLCF) and GloVis. The primary data involved personal observation, taking of pictures and taking of locations of points using handheld Global Positioning System (GPS). The GPS was also used for ground-truthing during image classification. False colour composite of the images was created and then display for visual analysis. Prior to the field exercise, visual image interpretation and analysis was carried out which enabled the identification of different themes on the images based on their spectral characteristics. A subset of the study area was done in ERDAS imagine after a false colour composite of the images were composed. Idrisi TerrSet software was used in image classification employing the maximum likelihood classifier.

Table 1: Specifications of Satellite Imageries Used

\begin{tabular}{lllllll}
\hline Satellite & Path/Row & Sensor & $\begin{array}{l}\text { No of } \\
\text { Bands }\end{array}$ & Bands used & Date Acquired & $\begin{array}{l}\text { Spatial } \\
\text { Resolution }\end{array}$ \\
\hline Landsat & $187 / 55$ & TM & 7 & $\begin{array}{l}\text { NIR, R, G } \\
(4,3,2)\end{array}$ & $29 / 01 / 1986$ & $30 \mathrm{~m}$ \\
Landsat & $187 / 55$ & ETM+ & 8 & $\begin{array}{l}\text { NIR, R, G } \\
(4,3,2)\end{array}$ & $\begin{array}{l}21 / 12 / 2001 \& \\
12 / 01 / 2012 \\
16 / 02 / 2018\end{array}$ & $30 \mathrm{~m}$ \\
Landsat & $187 / 55$ & OLI & 11 & $\begin{array}{l}\text { NIR, R, G } \\
(5,4,3)\end{array}$ & $30 \mathrm{~m}$ \\
\hline
\end{tabular}




\section{STATISTICAL ANALYSIS}

Land Use/Land Cover Classification (1986, 2001, 2012 and 2018)

The results of the LULC changes classification of Tse Gavar community forest were presented using charts and figures for easy interpretation and illustration of all LULC classes identified at Tse Gavar community forest. Histograms of the classified images were used to provide information about the total area coverage of each class theme from the different images. Simple percentage tables were used for the statistical analysis. Change analysis was carried out to examine the change in farmland between 1986 -2018 in order to determine the extent deforestation.

Figure 2: Classified LULC Map of 1986 Generated from Landsat TM

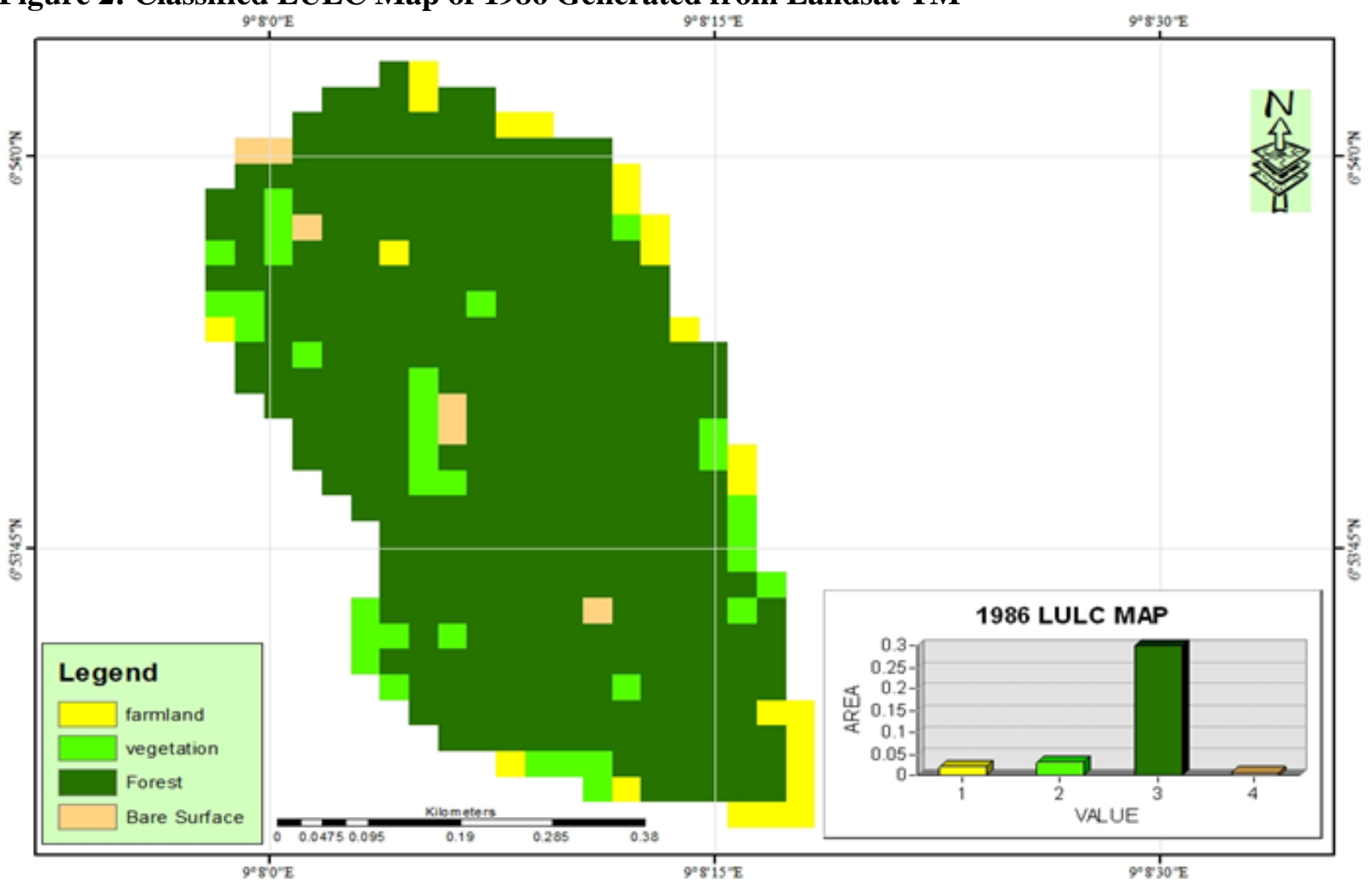

Source: (Researcher, 2019) 
East African Journal of Forestry and Agroforestry, Volume 2, Issue 1, 2020 Article DOI: https://doi.org/10.37284/eajfa.2.1.127

Figure 3: Classified LULC Map of 2001 Generated from Landsat TM

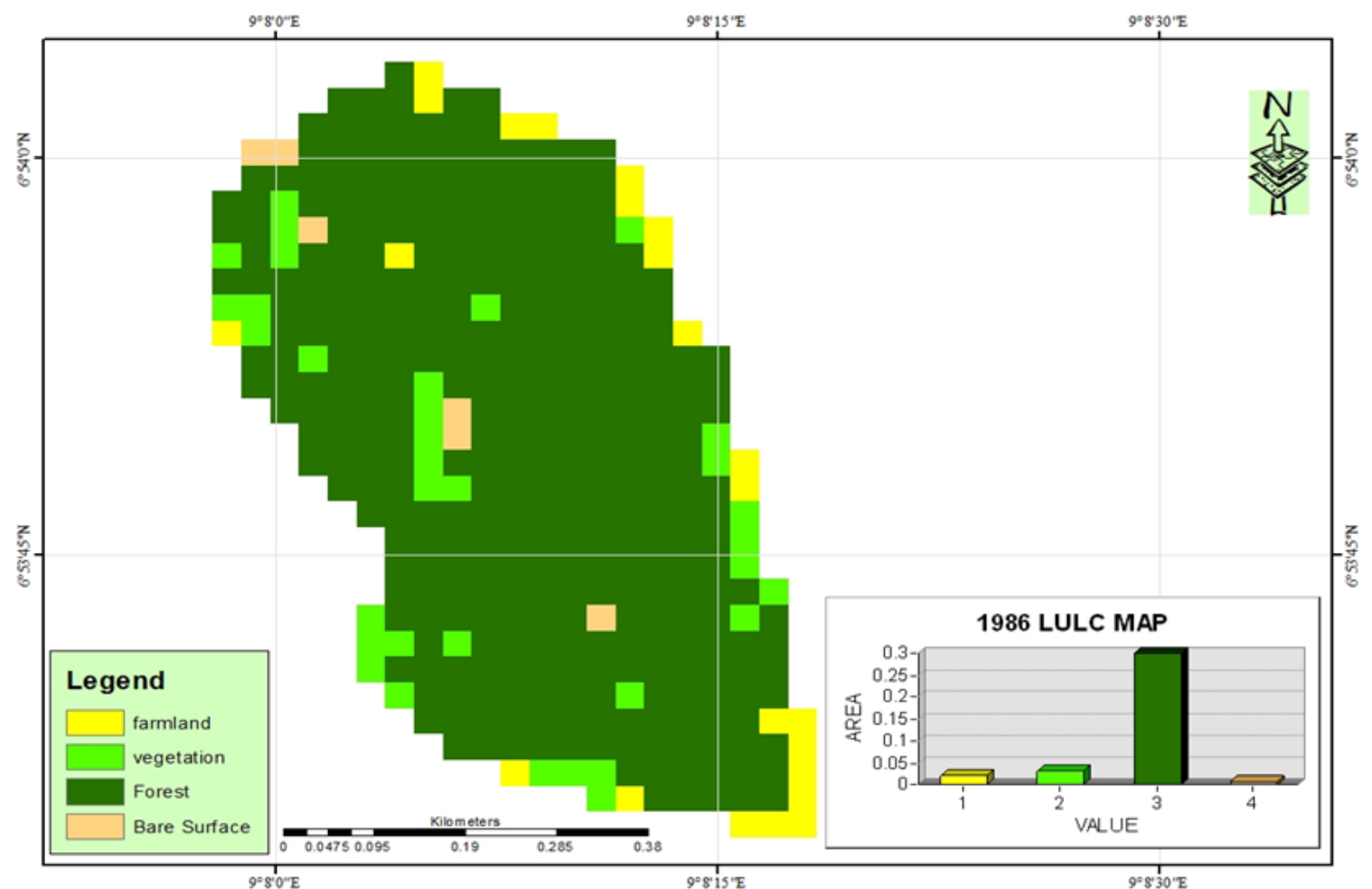

Source: (Researcher, 2019)

Figure 4: Classified Land Use and Land Cover Map of 2012 Generated from Landsat ETM+

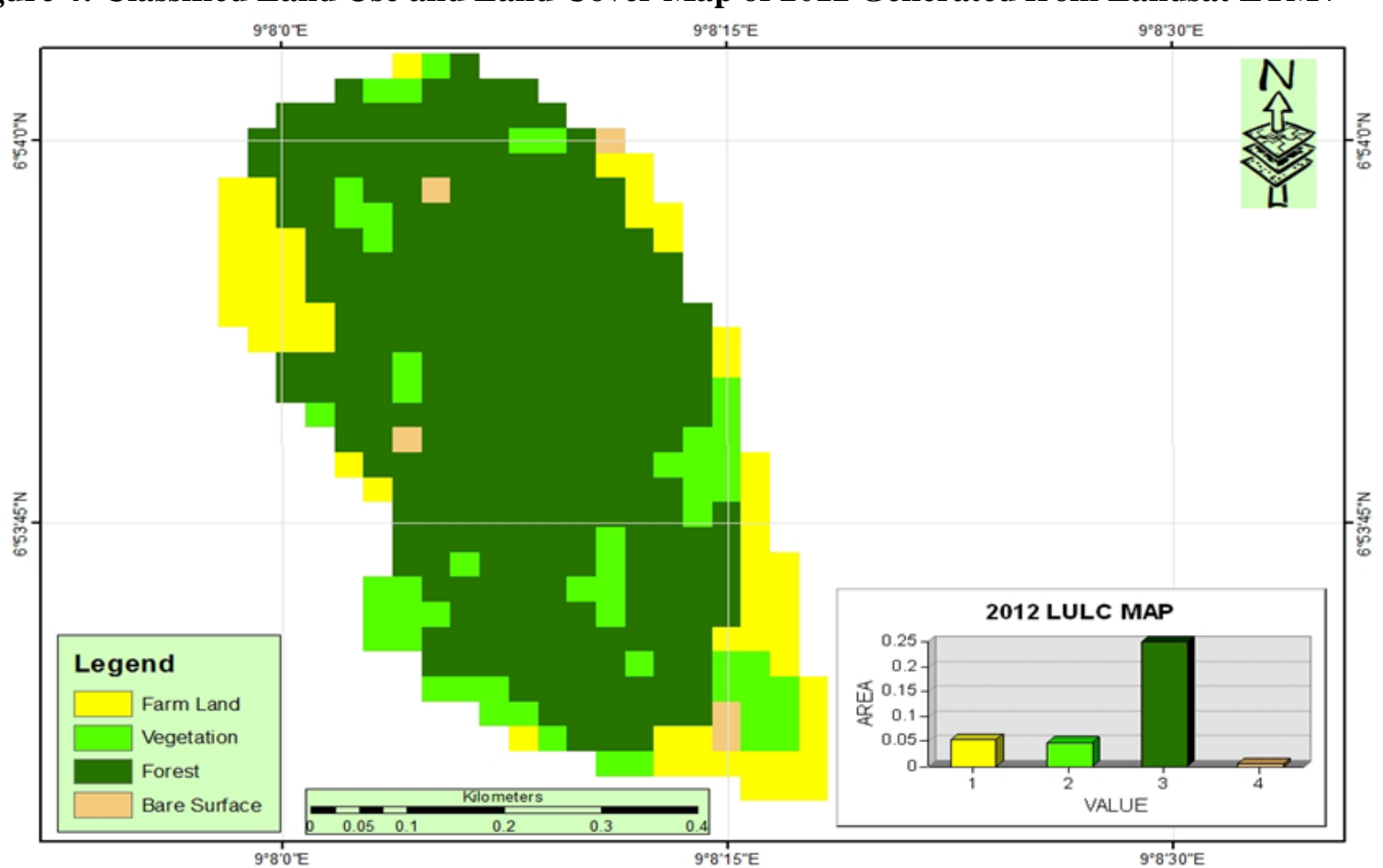

Source: (Researcher, 2019) 
Figure 5: Classified LULC map of 2018 generated from Landsat OLI

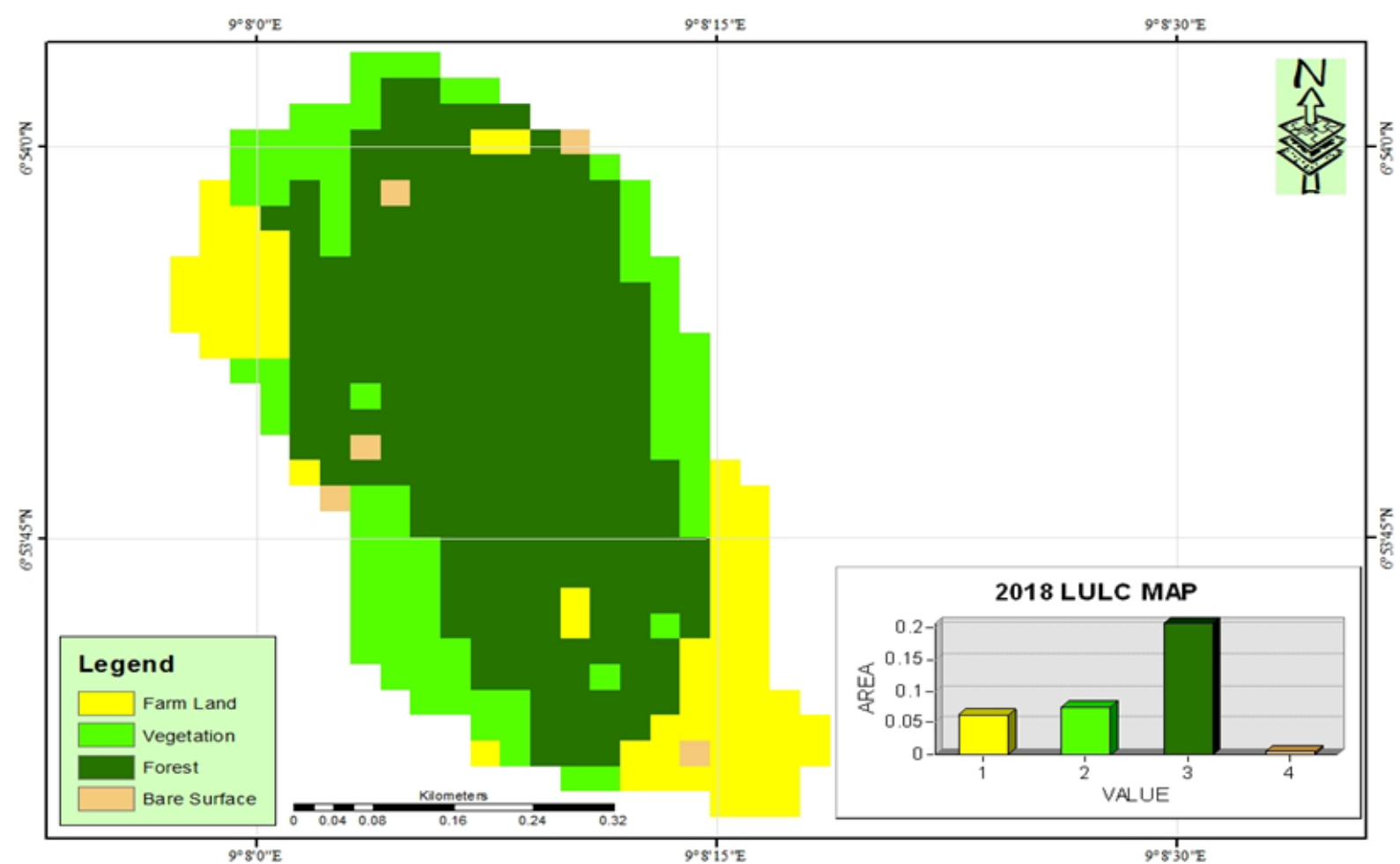

Source: (Researcher, 2019)

Table 2 below shows the results of accuracy assessment produced from the land use and land cover change maps of the study area (That is the producer, user and overall accuracy and kappa coefficient which were estimated using error matrix that revealed an accuracy of $80.77 \%$ in 1986 , $83.47 \%$ in $2001,87.35 \%$ in 2012 and $89.5 \%$ in
2018). In general, the general precisions of the classification are consistently high which shows a high level of conformity between classified image and land cover categories. These precisions agree with other studies carried out by Jande et al. (2018).

Table 2: Comparison of Classification Accuracy for 1986, 2001, 2012 and 2018

\begin{tabular}{|c|c|c|c|c|c|c|c|c|}
\hline \multirow[t]{2}{*}{ Class Name } & \multicolumn{2}{|l|}{1986} & \multicolumn{2}{|l|}{2001} & \multicolumn{2}{|l|}{2012} & \multicolumn{2}{|l|}{2018} \\
\hline & PA $(\%)$ & UA $(\%)$ & PA (\%) & UA $(\%)$ & PA $(\%)$ & UA $(\%)$ & PA $(\%)$ & UA $(\%)$ \\
\hline Farmland & 82.21 & 74.50 & 80.15 & 79.46 & 84.36 & 81.61 & 85.57 & 80.3 \\
\hline Other Vegetation & 90.43 & 85.60 & 89.67 & 81.00 & 85.19 & 74.39 & 98.00 & 95.00 \\
\hline Forest & 83.33 & 74.07 & 90 & 80.36 & 93.62 & 88 & 99.00 & 96.00 \\
\hline Bare surface & 81.93 & 79.07 & 91.67 & 86.84 & 82.05 & 100 & 95.00 & 90.00 \\
\hline Overall Accuracy & $80.77 \%$ & & $83.40 \%$ & & $87.35 \%$ & & $89.50 \%$ & \\
\hline Overall Kappa & 0.80 & & 0.83 & & 0.84 & & 0.88 & \\
\hline
\end{tabular}

PA-Producer's Accuracy $\quad \boldsymbol{U A}-$ User's Accuracy 
East African Journal of Forestry and Agroforestry, Volume 2, Issue 1, 2020

Article DOI: https://doi.org/10.37284/eajfa.2.1.127

\section{RESULT ANALYSIS AND DISCUSSION}

Table 3 reveals the data of various LULC types including their area coverage over the study periods, their percentage growth under the period of study and differences in hectares.

Table 3: Percentage of LULC in Tse Gavar Forest Reserve (1986, 2001, 2012 and 2018)

\begin{tabular}{lllllllll}
\hline $\begin{array}{l}\text { Classification } \\
\text { Category }\end{array}$ & $\begin{array}{l}\mathbf{1 9 8 6} \\
\text { Area } \\
(\mathbf{H a})\end{array}$ & $\begin{array}{l}\text { Area } \\
(\mathbf{\%})\end{array}$ & $\begin{array}{l}\mathbf{2 0 0 1} \\
\mathbf{A r e a} \\
(\mathbf{H a})\end{array}$ & $\begin{array}{l}\text { Area } \\
(\mathbf{\%})\end{array}$ & $\begin{array}{l}\mathbf{2 0 1 2} \\
\text { Area } \\
(\mathbf{H a})\end{array}$ & $\begin{array}{l}\text { Area } \\
(\mathbf{\%})\end{array}$ & $\begin{array}{l}\mathbf{2 0 1 8} \\
\text { Area } \\
(\mathbf{H a})\end{array}$ & $\begin{array}{l}\text { Area } \\
(\mathbf{\%})\end{array}$ \\
\hline Farm land & 2.07 & 5.78 & 3.33 & 9.3 & 5.4 & 15.15 & 6.39 & 18.25 \\
Other Vegetation & 3.06 & 8.54 & 4.59 & 12.81 & 4.77 & 13.38 & 7.38 & 21.08 \\
Forest & 30.15 & 84.17 & 27.72 & 77.39 & 25.02 & 70.2 & 20.79 & 59.38 \\
Bare surface & 0.54 & 1.5 & 0.18 & 0.5 & 0.45 & 1.26 & 0.45 & 1.29 \\
Total & 35.82 & 100 & 35.82 & 100 & 35.82 & 100 & 35.82 & 100 \\
\hline
\end{tabular}

\section{Extent of LULC Change in Tse Gavar community forest from $1986-2001$}

The result of the extent of LULC change from 1986 to 2001 in Table 3 revealed that farmland rose from $2.7 \mathrm{Ha}(5.78 \%)$ in 1989 to $3.33 \mathrm{Ha}(9.3 \%)$ in 2001 that is by $1.26 \mathrm{Ha}$ representing a $3.52 \%$ increment. Other vegetation also increased from $3.06 \mathrm{Ha}$ (8.54\%) in 1986 to $4.59 \mathrm{Ha}(12.8 \%)$ in 2001, an increment of $1.53 \mathrm{Ha}(4.27 \%)$. Forest, on the other hand, decreased from $30.15 \mathrm{Ha}(84.17 \%)$ in 1986 to $27.72 \mathrm{Ha}(77.39 \%)$ in 2001, a decline of $2.43 \mathrm{Ha}$ $(6.78 \%)$. Whilst, bare surface also decreased from $0.54 \mathrm{Ha}(1.5 \%)$ in 1986 to $0.18 \mathrm{Ha}(0.5 \%)$ in 2001 , a decline of $0.36 \mathrm{Ha}(1 \%)$. The increment in farmland and other vegetation and the decline in the forest and bare surface revealed by the findings are all in line with the works of Jande et al. (2018) who conducted research on Yandev forest reserve using a similar approach.

\section{Extent of LULC change in Tse Gavar community forest from $2001-2012$}

The result of the extent of LULC change from 2001 2012 in Table 3 indicates that farmland rose from $3.33(9.3 \%)$ in 2001 to $5.4 \mathrm{Ha}(15.15 \%) 2012$, accounting for an increase of $2.07 \mathrm{Ha}(5.85 \%)$. Vegetation also increases from $4.59 \mathrm{Ha}(12.81 \%)$ in 2001 to $4.77 \mathrm{Ha}(13.38 \%)$ in 2012 , a $0.18 \mathrm{Ha}$ $(0.57 \%)$ increment. However, forest shows a decline from $27.72 \mathrm{Ha}(77.39 \%)$ in 2001 to 25.02 $\mathrm{Ha}(70.2 \%)$ in 2012 , a decline of $2.7 \mathrm{Ha}(7.19 \%)$. The bare surface increased from $0.18 \mathrm{Ha}(0.5 \%)$ in 2001 to $0.45 \mathrm{Ha}(1.26 \%)$ in 2012, an increment of
$0.27 \mathrm{Ha}(0.76 \%)$. These findings also resonate with the findings by Ogunmola et al. (2014) who conducted research on LULC change in YelwaHeipang, Nigeria

\section{Extent of LULC Change in Tse Gavar community forest from $2012-2018$}

Table 3 reveals the extent of LULC changes in Tse Gavar community forest from 2012 to 2018. Farmland increased from 5.4 Ha (15.15\%) in 2012 to $6.39 \mathrm{Ha}(18.25 \%)$ in 2018, an increment of 0.99 $\mathrm{Ha}(3.1 \%)$ while vegetation also increased from $4.77 \mathrm{Ha}(13.38 \%)$ in 2012 to $7.38 \mathrm{Ha}(21.08 \%)$ in 2018 , an increase of $2.61 \mathrm{Ha}(7.7 \%)$. Furthermore, forest shows a decline from $25.02 \mathrm{Ha}(70.2 \%)$ in 2012 to $20.79 \mathrm{Ha}(59.38 \%)$ in 2018 , a $10.82 \%$ (4.32 $\mathrm{Ha})$ decline. The bare surface, on the other hand, increased from $0.45 \mathrm{Ha}(1.26 \%)$ in 2012 to $0.46 \mathrm{Ha}$ $(1.29 \%)$ in 2018 by just $0.01 \mathrm{Ha}$ with a percentage increase of $0.03 \%$. The findings above also resonate with findings by Ogunmola et al. (2014) whose work conducted in Plateau State shows a similar result.

\section{Extent of LULC Change in Tse Gavar community forest from $1986-2018$}

Similarly, the results presented in Table 3 indicates the extent of LULC changes in Tse Gavar community forest within the period $1986-2018$ shows that farmland increased tremendously within the period from $2.07 \mathrm{Ha}(5.78 \%)$ in 1986 to $6.39 \mathrm{Ha}$ $(18.25 \%)$ in 2018. This increment was by $4.32 \mathrm{Ha}$, accounting for the percentage increase of $16.18 \%$ in this time frame. Vegetation also showed a 
tremendous increase from $3.06 \mathrm{Ha}(8.54 \%)$ in 1986 to $7.38 \mathrm{Ha}(21.08 \%)$ in 2018 ; an increase of 4.32 Ha accounting for $12.45 \%$ rise.

Forest cover, on the other hand, declined from $30.15 \mathrm{Ha}(84.17 \%)$ in 1986 to $20.79 \mathrm{Ha}(59.38 \%)$ in 2018, a decline of $9.36 \mathrm{Ha}(24.79 \%)$. The bare surface showed an initial cascading movement in growth. That is an initial decline in growth from $0.54 \mathrm{Ha}(1.5 \%)$ in 1986 to $0.18 \mathrm{Ha}(0.5 \%)$ in 2001 , reducing by $0.36 \mathrm{Ha}$ with a percentage decrease of $1 \%$. However, there was an increase between 2001 and 2018, that is, an increase from $0.18 \mathrm{Ha}(0.5 \%)$ in 2001 to $0.46 \mathrm{Ha}(1.29 \%)$ in 2018 . The increment within this period is $0.28 \mathrm{Ha}$ accounting for a growth rate of $0.79 \%$. These findings are similar to the works of Jande et al., (2018) and Ogunmola et al., (2014) who accessed the conditions of some forest reserves using similar approaches.

Extent of Forest LULC Changes in 1986, 2001, 2012 and 2018

Table 4 revealed the extent of forest cover across the years under consideration. The extent of forest land cover changes in Tse Gavar community forest in 1986, 2001, 2012 and 2018 as presented in Table 4 shows that between 1986 and 2001, there was a decrease of $2.43 \mathrm{Ha}$ of forest land representing $6.78 \%$. Between 2001 and 2012 there was a further decrease in the forest land by $2.70 \mathrm{Ha}$, representing $7.19 \%$, while between 2012 and 2018, the decreasing rate had gone up to $4.23 \mathrm{Ha}$ representing $10.82 \%$. From the above, it is seen that there was an increasing decrease rate in percentage of the forest land in Tse Gavar community forest from $6.78 \%$ to $7.19 \%$ and then to $10.82 \%$ between 1986 and 2001, 2001 and 2012, 2012 and 2018 respectively. This continuous percentage increase in the deceasing rate in forest land can be traced to human activities of diverse nature that hamper the growth rate of the forest land. Other reasons that lead to this continuous decrease in the forest land can be due to continuous population growth in the area, agricultural activities, and deforestation among others. Between 1986 and 2001 covering 16 years, forest land decreased by $2.43 \mathrm{Ha}(6.78 \%)$. However, from 2001 to 2012 covering 12 years, forest land in the reserve decrease further by $2.7 \mathrm{Ha}$ (7.19\%) while between 2012 to 2018 forest lands continued to decrease to $4.73 \mathrm{Ha}(10.82 \%)$. This decline is a revelation of incessant conversion of the forest area to other forms of land use such as Logging, farming other anthropogenic activities.

Table 4: The Extent of Forest Land Cover Change in 1986, 2001, 2012 and 2018

\begin{tabular}{llll}
\hline S/N & Year & Area (Ha) & $\mathbf{( \% )}$ \\
\hline 1 & 1986 & 30.15 & 84.17 \\
2 & 2001 & 27.72 & 77.39 \\
3 & 2012 & 25.02 & 70.2 \\
4 & 2018 & 20.79 & 59.38 \\
\hline
\end{tabular}

\section{Land Use/ Land Cover Comparison Chart}

Figure 6 shows a representation of the changes that took place among the various LULC classes within the period in Tse Gaver forest reserve. The chart indicates that the forest area has been decreasing continuously from the base year to the reference year. Farmland and other vegetations, in contrast, shows an incessant increasing rate from the base year to the reference year over time. The bare surface, however, shows an up-down movement between the base year and 2001, but further show an upward movement between 2001 and the reference year. This increase is due to incessant anthropogenic activities in the area for one socioeconomic reason or the other. 
Figure 6: Land Use and Land Cover Comparison Chart

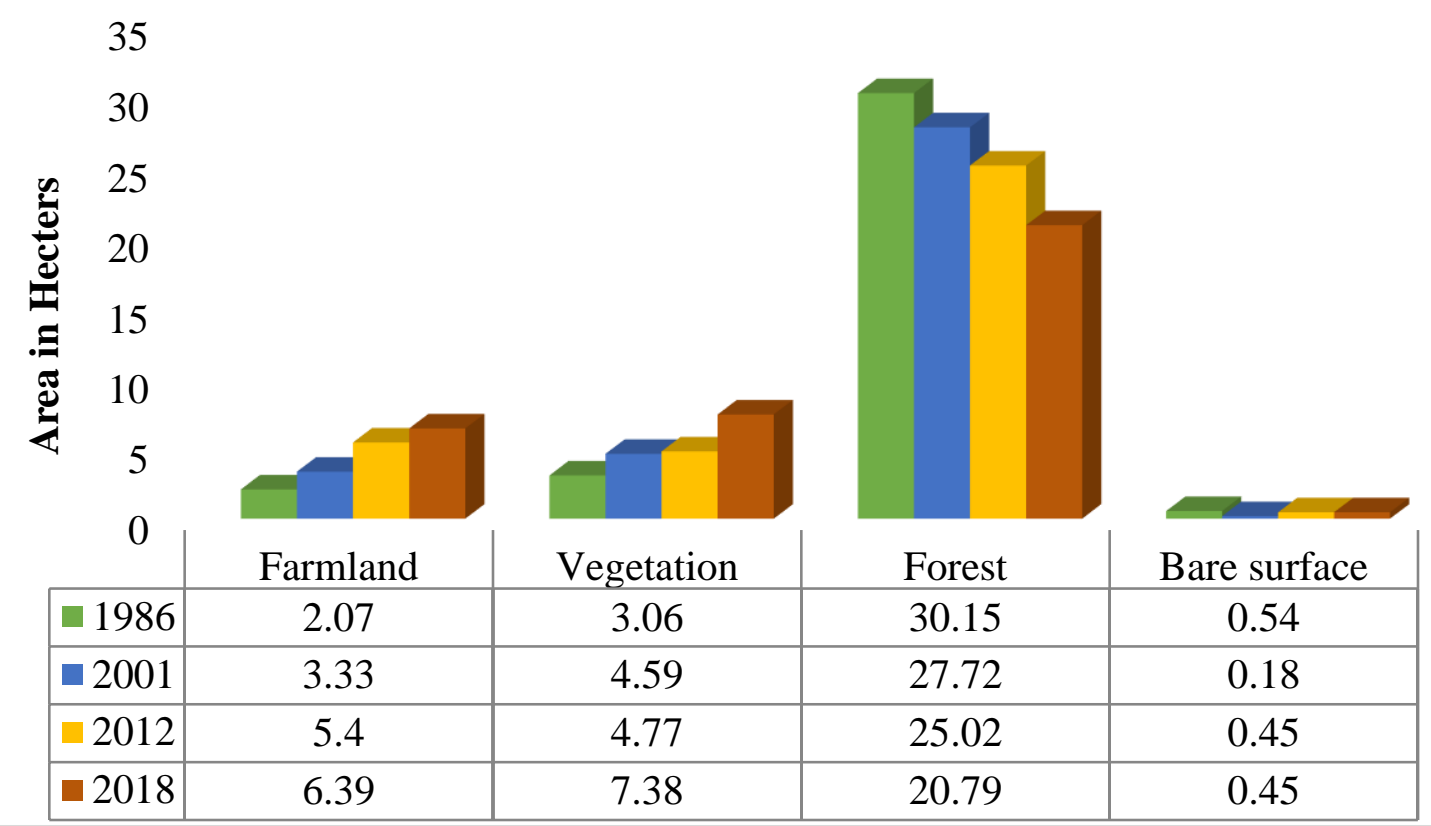

\section{Magnitude of Land Use/Land Cover Change}

The magnitude of forest change for 15 years between 1986 and 2001 showed that forest decreased by 2.43 ha representing a change $(43.55 \%)$ of the total change for the period as shown in Table 5. Forest had the highest annual rate of change of $6.53 \%$ while bare land had the least annual rate of change of $0.97 \%$. These agree with the findings of several authors such as Jande and Amonjenu (2018) who opined that natural vegetations of many communities in Nigeria are on a decline in recent years. This, however, disagreed the findings of Ikusemoran (2009) in Kainji Lake Basin, which shows increment riparian forest $16.96 \%$. This may be attributed to proper monitoring and strict enforcement of protection laws in Kainji, which is a National Park as opposed to Tse Gavar community forest which is a community forest. As a community forest, there may be inadequate monitoring in some instances. The period observed an increase in the farm area. The farm area increased by 1.26 ha representing $22.58 \%$ with an annual rate of $3.39 \%$. The changes observed in reserve may be due to human activities such as farm expansion and logging amongst others stimulated by population growth. Similarly, there was an increase in other vegetations by $27.42 \%$, while on the other hand there was a decrease in forest area $-2.43 \mathrm{ha}(43.55 \%)$ and Bare land to -0.36 ha $(6.45 \%)$ respectively (Table 5$)$.

Table 5: Magnitude and Percentage of Change in LULC between 1986 and 2001

\begin{tabular}{llllll}
\hline LULC Class & $\begin{array}{l}\mathbf{1 9 8 6} \\
\text { Extent } \\
(\text { Ha) }\end{array}$ & $\begin{array}{l}\mathbf{2 0 0 1} \\
\text { Extent }(\mathbf{H a})\end{array}$ & $\begin{array}{l}\text { Magnitude of } \\
\text { Change (Ha) }\end{array}$ & $\begin{array}{l}\text { Percentage } \\
\text { of Change }\end{array}$ & $\begin{array}{l}\text { Annual Rate } \\
\text { of Change \% }\end{array}$ \\
\hline Farm land & 2.07 & 3.33 & 1.26 & 22.58 & 3.39 \\
Other Vegetation & 3.06 & 4.59 & 1.53 & 27.42 & 4.11 \\
Forest & 30.15 & 27.72 & -2.43 & 43.55 & 6.53 \\
Bare surface & 0.54 & 0.18 & -0.36 & 6.45 & 0.97 \\
Total & $\mathbf{3 5 . 8 2}$ & $\mathbf{3 5 . 8 2}$ & $\mathbf{5 . 5 8}$ & $\mathbf{1 0 0}$ & $\mathbf{1 5 . 0 0}$ \\
\hline
\end{tabular}


Table 6 revealed that, the 11 years period of 2001 to 2012 witnessed an incessant reduction of the forest reserve as -2.7 ha which is $51.72 \%$. This was higher than $43.55 \%$ recorded from 1986 to 2001. It was observed that most of the parts affected by this reduction were inside and could not be easily noticed. Those areas closer to the roads were not affected. The percentage annual rate of change recorded by forest area in this study in 11 years was higher than the recorded by Ogar et al. (2014) in Stubb Creek Reserve in Akwa Ibom state in 10 years. It was equally higher than those recorded by Jande et al. (2018) within a similar period in the same State.

Similarly, the farmland area goes up by 2.07 ha which is equivalent to $39.66 \%$ of the entire change. This indicates that the increment recorded in those 11 years was higher than the one recorded in the first 15 years (from 1986 to 2001). This may be attributed to an increase in anthropogenic activities as the population of the area continue to expand, resulting in the scarcity of land. This resulted in the encroachment of the reserve as the forest area is being converted into farmland. Also, other vegetation cover increased further to 0.18 ha $(3.45 \%)$ while the bare surface increased by 0.27 ha $(5.17 \%)$

Within the period of 32 years, (1986 to 2018), the magnitude of change in reserve revealed that the forest land cover was the most affected land use and the land cover reason being that it is a forest reserve. It lost 9.36 ha $(51.74 \%)$ to other land cover category with annual rate change of $16.54 \%$ (Table 7). This implies that $16 \%$ of forest parts of the reserve were lost every year for 32 years. This figure was more than the annual rate of change reported by Jande and Amonjenu (2018) in their study in Apa,
Nigeria. It was also more than the figures reported by Oyinloye et al. (2018) in their study in forest reserves in Southwestern Nigeria.

Farmland and vegetation area increased by 4.32 ha (23.88\%) respectively between 1986 and 2018 at an annual rate of $7.64 \%$ which was the second-highest. This result indicates that $7.64 \%$ of Tse Gavar community forest was converted yearly for farming activities and other vegetation resulting mainly from deforestation and other human activities within the period of study. Ikusemoran and Olokor (2014) also reported farm expansion around a protected area in their study. More so, bare surface areas were covered by a decline of 0.09 ha $(0.49 \%)$ at an annual rate of $0.16 \%$. The loss of Natural vegetation in Tse Gavar community forest was linked to the in the encroachment of residents within the forest into the reserve. The findings of the study are in line with Ogunmola et al., (2014) who concluded that an increase in population will continue to be a major factor behind environmental resources degradation. This was also in agreement with Carr (2004) who opined that rapid population growth has resulted in many environmental challenges that have shot up deforestation and loss of vegetation in urban fringes. This is because as the population of an area goes up, more land will be needed for food production through farming, similarly more land will be needed to build houses and other construction, little will be left as forest area or fallow land. The implication of this is that Tse Gavar community forest will in no distant future be deforested and converted to different land use land cover classes which will lead to a decline in biodiversity, increased soil erosion and land degradation and habitat destruction.

Table 6: Magnitude and Percentage Change in LULC between 2001 and 2012

\begin{tabular}{llllll}
\hline LULC Class & $\begin{array}{l}\text { 2001 Extent } \\
\text { (Ha) }\end{array}$ & $\begin{array}{l}\text { 2012 Extent } \\
\text { (Ha) }\end{array}$ & $\begin{array}{l}\text { Magnitude } \\
\text { of } \\
\text { Change (Ha) }\end{array}$ & $\begin{array}{l}\text { Percentage } \\
\text { of Change }\end{array}$ & $\begin{array}{l}\text { Annual Rate } \\
\text { of Change } \\
\text { \% }\end{array}$ \\
\hline Farm land & 3.33 & 5.4 & 2.07 & 39.66 & 1.39 \\
Vegetation & 4.59 & 4.77 & 0.18 & 3.45 & 3.67 \\
Forest & 27.72 & 25.02 & -2.7 & 51.72 & 5.94 \\
Bare surface & 0.18 & 0.45 & 0.27 & 5.17 & 0 \\
Total & $\mathbf{3 5 . 8 2}$ & $\mathbf{3 5 . 8 2}$ & $\mathbf{5 . 2 2}$ & $\mathbf{1 0 0}$ & \\
\hline
\end{tabular}


East African Journal of Forestry and Agroforestry, Volume 2, Issue 1, 2020

Article DOI: https://doi.org/10.37284/eajfa.2.1.127

Table 7: Magnitude and Percentage Change LULC between 1986 and 2018

\begin{tabular}{llllll}
\hline LULC Class & $\begin{array}{l}\mathbf{1 9 8 6} \\
\text { Extent }(\mathbf{H a})\end{array}$ & $\begin{array}{l}\mathbf{2 0 1 8} \\
\text { Extent }(\mathbf{H a})\end{array}$ & $\begin{array}{l}\text { Magnitude } \\
\text { of } \\
\text { Change (Ha) }\end{array}$ & $\begin{array}{l}\text { Percentage } \\
\text { of Change }\end{array}$ & $\begin{array}{l}\text { Annual Rate } \\
\text { of Change \% }\end{array}$ \\
\hline Farm land & 2.07 & 6.39 & 4.32 & 23.88 & 7.64 \\
Other Vegetation & 3.06 & 7.38 & 4.32 & 23.88 & 7.64 \\
Forest & 30.15 & 20.79 & -9.36 & 51.74 & 16.56 \\
Bare surface & 0.54 & 0.42 & -0.09 & 0.49 & 0.16 \\
Total & $\mathbf{3 5 . 8 2}$ & $\mathbf{3 5 . 8 2}$ & $\mathbf{1 8 . 0 9}$ & $\mathbf{1 0 0}$ & $\mathbf{3 2 . 0 0}$ \\
\hline
\end{tabular}

\section{CONCLUSION}

The results of the analysis established that there was a tremendous change in the land cover and land use in Tse Gavar community forest in the past 32 years period from 1986 to 2018 . The forest land cover is the most affected land use category reason been that it is a forest reserve. About 9.36 ha $(51.74 \%)$ of forest land was lost compared to other land cover categories with annual rate change of $16.54 \%$. This implies that $16 \%$ of forest land is been lost annually in the reserve for 32 years. Farmland and vegetation area increased by 4.32 ha $(23.88 \%)$ respectively between 1986 and 2018 at an annual rate of $7.64 \%$ which was the second-highest. This result indicates that $7.64 \%$ of Tse Gavar community forest is being converted yearly for farming activities and vegetation resulting mainly from deforestation and other activities during the study period. The rate of change in the forest area between 1986 and 2001 is $6.53 \%$ per annum that of 2001 and 2012 was $5.94 \%$ while that 1986 to 2018 is $16.56 \%$ per annum. Based on the finding of this research, it is recommended that there should be increased monitoring of forest reserves in the state be ensured and key stakeholders should be mobilized towards the sustainable use of the reserve. The use of GIS for prompt detection of land cover change should be encouraged. Also, the encouragement of planting of the already degraded areas of the reserves is carried out.

\section{REFERENCES}

Adedeji, O. H., Tope-Ajayi, O. O., \& Abegunde, O. L. (2015). Assessing and Predicting Changes in the Status of Gambari Forest Reserve, Nigeria Using Remote Sensing and GIS Techniques. Journal of Geographic Information System,
07(03), https://doi.org/10.4236/jgis.2015.73024

Agera, S. I. N., Adegeye, A. O., \& Jimoh, S. O. (2010). Appraisal of Taungya Farming as a Sustainable Land-use option in Vandeikya Local Government of Benue State, Nigeria. Journal of Research in Forestry, Wildlife and Environment, 2 (1), 32-43.

Carr, D. L. (2004). Proximate Population Factor and Deforestation in Tropical Agriculture Frontiers. Popul. Environ, 25(6), 585-612.

DeFries, R., Hansen, A. J., Turner, B. L., Reid, R. \& Liu, J. (2007). Land-use change around protected areas: management to balance human needs and ecological function. Ecological Applications, 17, 1031-1038

Ellis, E. \& Pontius, R. (2010). Land-use and landcover change. In: Cleveland, C. J. (Eds), Encyclopedia of Earth. Washington, D.C.: Environmental Information Coalition, National Council for Science and the Environment.

FAO. (2018). The state of the World Forest. Forest Partways to Sustainable Development. Rome: Food and Agriculture Organization.

Faye, L. C., Sambou, H., Kyereh, B. \& Sambou, B. (2016). Land Use and Land Cover Change in a Community-Managed Forest in South-Eastern Senegal Under a Formal Forest Management Regime. American Journal of Environmental Protection, 5(1), 1-10.

Gabay, M. \& Rekola, M. (2019). Forests, peaceful and inclusive societies, reduced inequality, 
education, and inclusive institutions at all levels: Background study prepared for the fourteenth session of the United Nations Forum on Forests. Helsinki, Finland: Department of Forest Sciences, University of Helsinki.

Ikusemoran, M. (2009). Landuse and landcover change detection in the Kainji Lake Basin Nigeria using remote sensing and GIS approach. Bayero Journal of Pure and Applied Sciences, 2(1), 83-90.

Ikusemoran, M., \& Olokor, J. O. (2014). Monitoring the land-use and vegetation cover changes in the Kainji Lake Basin, Nigeria (1975-2006). African Journal of Environmental Science and Technology, 8(2), 129-142.

Iorkosu, T. S., Alugwa, E. D., Akor, D. N., Dzungwe, C. N., Torkobo, J. N., \& Orngu, A. G. (2019). An Assessment of Health Practices of Those Who Live Long: A Study of Elderly Persons in Vandeikya L G A of Benue State, Nigeria. World Journal of Innovative Research (WJIR), 6 (6), 132-142.

Jande, J. A., Kwaghkohol, G. T. \& Ikyaagba, E.T. (2018). Assessing the Status of Yandev Forest Reserve Using Remote Sensing and Geographic Information System (GIS) Techniques. Asian Journal of Research in Agriculture and Forestry, 2(2), 1-13,

Laurance, W. F. (2010). Habitat destruction: death by a thousand cuts. In Sodhi, N. S. and Ehrlich, P.R. (Eds), Conservation Biology for All (p. 7386). Oxford: Oxford University Press.

Mohammed, S. O.; Gajere, E. N.; Eguaroje, E. `O., Shaba, H., Ogbole, J.O., Mangut, Y.S, Onyeuwaoma, N.D. \& Kolawole, I. S. (2013). Spatio-Temporal Analysis of the National Parks in Nigeria using Geographic Information System. Ife Journal of Science, 15 (1), 159-166.

Ogar, D.A., Asuk, S.A. \& Umanah, I.E. (2016) Forest Cover Change in Stubb's Creek Forest Reserve Akwa Ibom State, Nigeria. Applied Tropical Agriculture, 21(1), 183-189.
Ogunmola, J. K., Gajere, E. N., Jeb, D. N., \& Agene, I. J. (2014). Study of landcover change in Yelwa-Heipang area of Plateau State, northcentral Nigeria: A geoinformatics approach. International Archives of the Photogrammetry, Remote Sensing and Spatial Information Sciences - ISPRS Archives, 40(1), 331-337. https://doi.org/10.5194/isprsarchives-XL-1331-2014

Oyinloye, R. O., Adesina, F. A. \& Salami, A. T. (2010). An Assessment of the State of Forest Reverses in Southwestern Nigeria. Ife Research Publications in Geography, 9(1), 155-175.

Powell, B., A, I., McMullin, S., Jamnadass, R., Padoch, C., Pinedo-Vasquez, M., \& Sunderland, T. (2013). The role of forests, trees and wild biodiversity for nutrition-sensitive food. International Conference on Nutrition. (pp. 1-25).

Sala, O. E., Chapin, F. S., Armesto, J. J., Berlow, E., Bloomfield, J., Dirzo, R., Huber-Sanwald, E., Huenneke, L. F., ... Wall, D. H. 2000. Biodiversity - global biodiversity scenarios for the year 2100. Science, 287, 1770-1774.

Scholte, P. (2011). Towards understanding large mammal population declines in Africa's protected areas: A West-Central African perspective. Journal - Tropical Conservation Science, 4 (1), 1-11. 